\title{
Regular dorsal dimples and damaged mites of Varroa destructor in some Iranian honey bees (Apis mellifera)
}

\author{
Masoud M. Ardestani • Rahim Ebadi • Gholamhossein Tahmasbi
}

Received: 21 November 2010/ Accepted: 7 March 2011/Published online: 24 March 2011

(C) The Author(s) 2011. This article is published with open access at Springerlink.com

\begin{abstract}
The frequency of damaged Varroa destructor Anderson and Trueman (Mesostigmata: Varroidae) found on the bottom board of hives of the honey bee, Apis mellifera L. (Hymenoptera: Apidae) has been used as an indicator of the degree of tolerance or resistance of honey bee colonies against mites. However, it is not clear that this measure is adequate. These injuries should be separated from regular dorsal dimples that have a developmental origin. To investigate damage to Varroa mites and regular dorsal dimples, 32 honey bee (A. mellifera) colonies were selected from four Iranian provinces: Isfahan, Markazi, Qazvin, and Tehran. These colonies were part of the National Honey bee Breeding Program that resulted in province-specific races. In April, Varroa mites were collected from heavily infested colonies and used to infest the 32 experimental colonies. In August, 20 of these colonies were selected (five colonies from each province). Adult bees from these colonies were placed in cages and after introducing mites, damaged mites were collected from each cage every day. The average percentage of injured mites ranged from 0.6 to $3.0 \%$ in four provinces. The results did not show any statistical differences between the colonies within provinces for injuries to mites, but there were some differences among province-specific lines. Two kinds of injuries to the mites were observed: injuries to legs and pedipalps, and injuries to other parts of the body. There were also some regular dorsal dimples on dorsal idiosoma of the mites that were placed in categories separate from mites damaged by bees. This type of classification helps identifying damage to mites and comparing them with developmental origin symptoms, and may provide criteria for selecting bees tolerant or resistant to this mite.
\end{abstract}

\footnotetext{
M. M. Ardestani ( $₫)$

Department of Animal Ecology, Faculty of Earth and Life Sciences, VU University, De Boelelaan 1085, 1081 HV Amsterdam, The Netherlands e-mail: masoud.mortazavi@falw.vu.nl

R. Ebadi

Department of Entomology, College of Agriculture, Isfahan University of Technology, 84156 Isfahan, Iran

G. Tahmasbi

Honey bee Department, Animal Sciences Research Institute, P.O.Box 31585-1483, Karaj, Iran
} 
Keywords Varroa destructor $\cdot$ Regular dorsal dimples $\cdot$ Grooming behaviour

\section{Introduction}

The honey bee, Apis mellifera L. (Hymenoptera: Apidae), is of great economic importance for crop pollination and honey production. The ectoparasitic mite, Varroa destructor Anderson and Trueman (Mesostigmata: Varroidae), is considered one of the most important parasitic agents affecting beekeeping. Varroa jacobsoni was first reported in Iran in 1984 (Mossadegh 1992). This mite, V. jacobsoni, was originally described as an ectoparasite of the Asian honey bee, Apis cerana, in Java, Indonesia in 1904. Infested bees try to remove the mites by vigorous movements and directed wiping with the legs. Occasionally mites can be observed being caught in a quick movement of the mandibles (autogrooming). If the infested bee fails to remove the mite, it may obtain grooming assistance from its nestmates by performing a specific shaking dance, with fast lateral movements of the abdomen. Nestmates inspect the whole body, paying greater attention to the petiolus region and the wing bases (allogrooming). Foreign particles are picked off with the mandibles and are eventually chewed (Peng et al. 1987b).

Resistance mechanisms of honey bees to Varroa mites have been described by several authors (Arechavaleta-Velasco and Guzman-Novoa 2001; Guzman-Novoa et al. 1999; Medina 1998; Boecking 1999; Boecking and Ritter 1994). Research done on honey bee grooming behaviour against Varroa is summarized in Table 1. Lodesani et al. (1996) studied the differences between mites present on adult bees and those fallen on the bottom boards for nine days. Damaged mites were divided on the following basis: single or double hollow on dorsal shield, mutilation or amputation of one or more legs, and multiple kinds of damage. The average percentage of damaged mites on the bottom boards was $24 \%$, whereas it was $46 \%$ in traps in front of the hive. This indicated that damaged mites had been removed from the hive.

General studies of grooming behaviour (independent of its effect on mites) showed that some A. mellifera were grooming specialists; the behaviour is genetically determined and age specific (Danka and Villa 1998). Peng et al. (1987a) observed that in A. cerana colonies, $22.5 \%$ of the inoculated mites were removed from the bee's body by self-cleaning behaviour (autogrooming) within $35 \mathrm{~s}$, and 7.5\% more were removed within 1-5 min by self-cleaning. Fries et al. (1996) mentioned that the mite source could also influence the results. They used only mites collected from adult bees of a heavily infested European colony, whereas Peng et al. (1987a) used both phoretic mites and mites collected from sealed brood.

In a recent paper, Davis (2009) showed that one or two dorsal hollows described as "regular dorsal dimples" originated during developmental ontogeny processes of mites inside the cells and they should be separated from mite damage from honey bee grooming. He pointed out that near $10.6 \%$ of mites had one $(8.1 \%)$ or two $(2.5 \%)$ diagonal dimple(s) on the dorsal idiosoma. This present survey was conducted to determine the grooming behaviour and regular dorsal dimples on Varroa mites in some honey bee colonies from the National Honey bee Breeding Program in Iran.

\section{Materials and methods}

Experiments were conducted at the Isfahan University of Technology research farm in the Southwest of Isfahan from 1999 to 2001 . Field work was started in July 1999. A National 
Table 1 Summary of research on honey bee grooming behaviour

\begin{tabular}{|c|c|c|c|c|}
\hline $\begin{array}{l}\text { Honey bee } \\
\text { species/sub } \\
\text { species }\end{array}$ & Place & Grooming (\%)/Damage type & $\begin{array}{l}\text { Varroa } \\
\text { species }\end{array}$ & References \\
\hline
\end{tabular}

\begin{tabular}{|c|c|c|c|c|}
\hline $\begin{array}{l}\text { Apis mellifera } \\
\quad \text { iberica }\end{array}$ & $\begin{array}{l}\text { Southern } \\
\text { Spain }\end{array}$ & $\begin{array}{l}\text { Damage in } 40 \% \text { of fallen mites (cf. } \\
\text { Lodesani et al. 1996, in } 30 \% \text { of mites) }\end{array}$ & V. jacobsoni & $\begin{array}{l}\text { Flores et al. } \\
\text { (1995) }\end{array}$ \\
\hline Apis dorsata & $\begin{array}{r}\text { Chiang Mai } \\
\text { (Thailand) }\end{array}$ & Autogrooming (for the first time) & $\begin{array}{l}\text { Tropilaelaps } \\
\text { clareae and } \\
\text { Varroa }\end{array}$ & $\begin{array}{l}\text { Buchler et al. } \\
\text { (1992) }\end{array}$ \\
\hline A. cerana & $\begin{array}{r}\text { Chiang Mai } \\
\text { (Thailand) }\end{array}$ & $\begin{array}{l}88.6 \% \text { autogrooming after } 60 \mathrm{~s}, 33.3 \% \\
\text { allogrooming after } 5 \mathrm{~min}\end{array}$ & Varroa & $\begin{array}{l}\text { Buchler et al. } \\
\text { (1992) }\end{array}$ \\
\hline A. mellifera & $\begin{array}{r}\text { Chiang Mai } \\
\text { (Thailand) }\end{array}$ & $\begin{array}{l}48 \% \text { autogrooming after } 5 \mathrm{~min}, \\
\text { allogrooming rare }\end{array}$ & Varroa & $\begin{array}{l}\text { Buchler et al. } \\
\text { (1992) }\end{array}$ \\
\hline
\end{tabular}

38 colonies

from 3 queen

families

$\begin{array}{cc}\text { Africanized } & \text { Ribeirao } \\ \text { bees }(A . m . & \text { Preto } \\ \text { scutellata) } & \text { (Brazil) } \\ \text { Italian bees }(A . & \text { Ribeirao } \\ m . \text { ligustica) } & \text { Preto } \\ & \text { (Brazil) }\end{array}$

A. m. carnica

A. mellifera

(A. $m$.

ligustica $\times$

A. $m$.

mellifera)

A. mellifera carnica

A. cerana and A. mellifera

European honey bee races

\section{A. mellifera carnica}

A. cerana
Most mites in cage tests fell in the first $48 \mathrm{~h}$ Varroa

$38.5 \%$ mite removal within 30 min after artificial infestation (30\% of damage mites in hive debris)

$5.75 \%$ mite removal at the same time period $V$. jacobsoni

\section{Moretto}

(1997)

Observation of grooming behaviour with infra-red video, proportion of damaged mites ( 9 and $15 \%$ ) in the expelled mites after $7 \mathrm{~h}$ (cf. Fries et al. 1996: 12.3\% damaged mites)

Argentina

$30 \%$ (annual average) of the dead mites collected from the bottom of hives, showing physical damage like mutilations in their appendages and, in a few cases, in the cuticle of the idiosoma

"Active defense", 30-50\% of dead mites showing damaged legs, specially first legs, and rarely damaged idiosoma

Varroa

Thakur et al. (1997)

V. jacobsoni Eguaras et al. (1995)

$30 \%$ damage to live mites in A. cerana compared to $12.5 \%$ in A. mellifera. Main type of damage was amputation or mutilation of one or more legs. Injuries to the mites' idiosoma or gnathosoma were relatively rare

Effective autogrooming with one or more legs and leg segments removal

Tracheal mite Danka and Villa (1998)

$80-90 \%$ of injuries to the mite (most damage to the first pair of mite legs in hive debris)

Damage to $2 \%$ of expelled mites, with a range of $0-9.8 \%$

Regular groomers groomed up to 8 recipients one after the other without breaks larger than 2 min

Varroa

Ruttner and

Hanel

(1992)

V. jacobsoni Boecking and Spivak (1999)

V. jacobsoni Chmielewski (1996)

V. jacobsoni Szabo (1999)

Varroa Bozic and Valentincic (1995)

A total of $73.8 \%$ of the mites were mutilated $V$. jacobsoni Peng et al. 
Table 1 continued

\begin{tabular}{|c|c|c|c|c|}
\hline $\begin{array}{l}\text { Honey bee } \\
\text { species/sub } \\
\text { species }\end{array}$ & Place & Grooming $(\%) /$ Damage type & $\begin{array}{l}\text { Varroa } \\
\text { species }\end{array}$ & References \\
\hline A. mellifera & & $\begin{array}{l}\text { Most damage to adult mites on the first pair } \\
\text { of legs }\end{array}$ & V. jacobsoni & $\begin{array}{l}\text { Bienefeld } \\
\text { et al. (1999) }\end{array}$ \\
\hline $\begin{array}{l}\text { A. mellifera } \\
\text { intermissa }\end{array}$ & Tunisia & $\begin{array}{l}\text { On average, } 19.3 \% \text { of damage in mite legs, } \\
3.7 \% \text { damage in live mites that still show } \\
\text { movements }\end{array}$ & V. jacobsoni & $\begin{array}{l}\text { Boecking and } \\
\text { Ritter } \\
\text { (1993) }\end{array}$ \\
\hline $\begin{array}{l}\text { Africanized and } \\
\text { Carniolan } \\
\text { honey bees }\end{array}$ & & $\begin{array}{l}\text { Africanized bees groomed faster than } \\
\text { Carniolan workers. Efficiency of } \\
\text { grooming more or less consistent with that } \\
\text { in Vandame et al. (1999) }\end{array}$ & V. destructor & $\begin{array}{r}\text { Aumeier } \\
(2001)\end{array}$ \\
\hline $\begin{array}{l}\text { A. mellifera } \\
\text { carnica }\end{array}$ & & $\begin{array}{l}37.2 \% \text { mortality in mites, } 3.2 \% \text { of them } \\
\text { damaged }\end{array}$ & Varroa & $\begin{array}{c}\text { Hoffman } \\
(1993)\end{array}$ \\
\hline
\end{tabular}

Honey bee Breeding Program had begun in Iran several years before this field work started and a pure line from each province was produced.

Thirty-two experimental colonies (A. mellifera) from the Program were transported to our farm that included colonies from Isfahan, Markazi, Qazvin and Tehran (eight colonies from each of the four provinces). In the middle of April and when the mite population had increased, Varroa mites were collected from heavily infested colonies using the method described below and pooled together before being distributed to the experimental cages. The main experiments were done between August and October. To separate mites from infested honey bees, an instrument was designed as described by Ariana et al. (2002) that had two cylinders, one inside the other. About 1000-2000 adult bees were poured into the inner cylinder and after closing the inner and outer cylinders they were exposed to $\mathrm{CO}_{2}$ gas for $5 \mathrm{~min}$ with $5 \mathrm{l} / \mathrm{min}$ pressure from a gas cylinder. After $5 \mathrm{~min}$, infested bees and mites were insensible and they were shaken several times until mites were separated. They were then removed from the cylinders and placed on a piece of white paper. The bees were then returned to their colonies and the live and healthy mites were collected with an aspirator and held in small glass containers for the main experiment.

For the main experiment, $15 \times 11 \times 15 \mathrm{~cm}$ cages were constructed. The top and bottom of these cages were made of wood and the sides were made of 8 -mesh screen (screen cell openings were $1.5 \mathrm{~mm}$ wide). A honey comb was attached to the top for resting and feeding bees in the cages. The bottom board of the cage was protected from the bees by a 10-mesh net (openings $1.7 \mathrm{~mm}$ ) and was covered with petroleum jelly (vaseline) to collect fallen mites. The cages were placed in an incubator $(1.5 \times 1.8 \times 2.5 \mathrm{~m})$ at $34 \pm 1^{\circ} \mathrm{C}$ and $40-60 \%$ r.h. during the experiments.

For investigation of grooming behaviour, mite infestation levels were examined in the 32 experimental colonies and 20 colonies (five from each province) were selected. Adult bees (100-200) were used to fill each cage. Five cages (replicates) from each province (treatments) were used. Mite infestation level was measured in each colony, using a sample of about 200 adult bees and shaking in a detergent solution (De Jong et al. 1982). Forty mites were introduced to each cage and they were left to climb on the bee bodies. A fine brush was used to help some of the mites to be in the right place. Every $24 \mathrm{~h}$, the number of fallen mites on the bottom boards was recorded and they were collected in special tubes for examination using a $40 \times$ dissecting microscope. Damage to bodies of the live and dead mites from grooming behaviour and the occurrence of regular dorsal dimples were recorded separately. 


\section{Results}

Mite infestation level in the colonies

Average provincial colony infestation levels were 7.3\% (Markazi), 10.9\% (Isfahan), 11.7\% (Tehran), and $12.0 \%$ (Qazvin). Infestation levels were not significantly different among colonies (ANOVA; $\mathrm{p}>0.5$ ); therefore, these colonies were used in the main experiment.

Injuries to Varroa mite caused by grooming behaviour

Results of the injury percentage of the mites caused by honey bee grooming behaviour and the percentage with regular dorsal dimples are shown in Table 2 . The highest injuries to mites $(6.5 \%)$ occurred in Qazvin province, and the lowest injuries $(0 \%)$ were in some of the colonies in different provinces. In Isfahan province, on average, the percentage of injuries was $1.1 \%$. In Markazi province, the mean percentage was $0.6 \%$ and in Qazvin and Tehran 3.0 and $0.9 \%$ of mites showed injuries, respectively. Statistical analysis did not show any significant differences between treatments (ANOVA; $P>0.5$ ).

Regular dorsal dimples

Regular dorsal dimples were seen in various provinces. In Isfahan, the average percentage of one regular dorsal dimple was $5.6 \%$, whereas two dorsal dimples were found in $3.5 \%$ of the colonies. In Markazi, mites showed $6.1 \%$ with one regular dorsal dimple and $1.8 \%$ with two dorsal dimples. In Qazvin, the averages were 4.0 and $1.3 \%$ with one and two regular dorsal dimples, respectively. Finally in Tehran, regular dorsal dimples were found between $3.9 \%$ with one dorsal dimple in dorsal idiosoma and $1.6 \%$ with two dorsal dimples.

Kinds of damage to the Varroa mite by honey bees

Damage to the legs

Honey bee workers detached the mites with their mandibles and injured their legs. As a result of the grooming behaviour, two or more mite legs were removed. In some samples, most of the mite legs were removed (Fig. 1). Most damage to mite legs (2.7\% on average) was found in Qazvin province, whereas damage to mite legs was $0.6 \%$ in Isfahan, $0.9 \%$ in Tehran and $0 \%$ in Markazi.

Table 2 Mean damage (\% individuals) of Varroa mites (total, legs and body), and mean occurrence (\% individuals) of regular dorsal dimples (one and two dimples) in each province

\begin{tabular}{lllllll}
\hline Provinces (treatments) & \multicolumn{2}{l}{$\%$} & & \multicolumn{2}{c}{$\%$ Regular dorsal dimples } \\
\cline { 2 - 3 } & Mites & Legs & Bodies & & Single & Double \\
\hline Isfahan & 1.14 & 0.57 & 0.57 & & 5.55 & 3.51 \\
Markazi & 0.60 & 0 & 0.60 & & 6.09 & 1.77 \\
Qazvin & 3.02 & 2.70 & 1.29 & & 3.98 & 1.29 \\
Tehran & 0.93 & 0.93 & 0 & & 3.85 & 1.55 \\
\hline
\end{tabular}



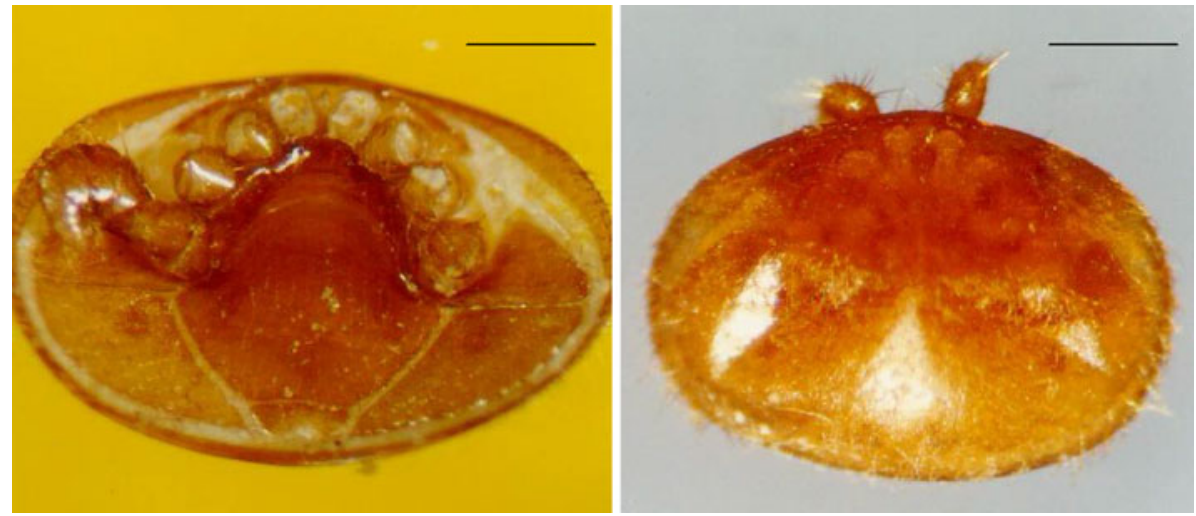

Fig. 1 Left leg-damaged mite as a consequence of grooming behaviour; right regular dorsal dimples on the mite dorsal idiosoma. Scale bars $=0.5 \mathrm{~mm}$

\section{Damage to the body}

According to this kind of damage, broken bodies, indentation and mutilation on the dorsal idiosoma were seen and measured in fallen mites. Also the ventral and dorsal shield may be damaged, and cracks in and pieces missing from the dorsal shield were found. Sometimes one or two depressions or hollows were seen in the dorsal shield of some fallen mites that, according to the recent research by Davis (2009), was categorized separate from grooming damage by honey bee mandibles (Fig. 1). Results of this kind of damage and also dorsal dimples are presented in Table 2. Qazvin had the highest percentage of mites with body damage (1.3\%). Markazi, Isfahan and Tehran had 0.6, 0.6 and $0 \%$, respectively.

Some of the fallen mites in this study were alive and after checking them by $40 \times$ dissecting microscope, we did not see any damaged mites among them. Some of these live mites had regular dorsal dimples.

\section{Discussion}

Apis cerana, the main host of Varroa, can successfully groom the mites from their bodies, whereas A. mellifera races removed infested worker pupae to a more limited extent compared to A. cerana (Boecking and Ritter 1994). Our results showed some similarities in mean percentage of mite damage to Lodesani et al. (1996). They mentioned that $10.2 \%$ of the mites had damage in brood cells and $24.2 \%$ of the mites in the hive debris. They described one or two double hollows on the dorsal shield as types of damage, which were later discussed as possible "accidental events in the growth stages of the nymphs or during the sclerotization process". Rosenkranz et al. (1997) also reported this kind of regular dimples and attributed them to "disturbances during the nymphal development". Morse et al. (1991) referred to these indentations in the dorsal shield and attributed them to worker bee mandibles. Harbo and Harris (1999) recorded different types of physical damage to mites and emphasized that mites possessed the dents on their idiosoma before they left brood cells for the first time. This implied that honey bee mandibles were not the cause of making these dents.

The frequency of regular dorsal dimples in the present study was consistent with the results of Davis (2009). We found 1.3-3.5\% of mites with two dimples and 3.9-6.1\% with 
one, whereas Davis (2009) reported 2.5 and $8.1 \%$, respectively. The regular dorsal dimples are produced during development of the mites inside honey bee cells and should not be considered as the result of grooming behaviour of honey bees. The location of these regular dorsal dimples was highly precise and predictable. The idiosomal dimples are caused by dorso-ventral muscles located on left and right of the Malpighian tubules and attached between the middle and posterior caecal lobes of the ventriculus. Then, these dimples showed bilateral symmetry. During expansion of the mite cuticle to reach its elliptical body shape and before sclerotization, the hydrostatic pressure is occasionally insufficient to inflate the large dorsal idiosomal cuticle. This may result in one or two regular dimples on the dorsal shield. It is improbable that leg movements of a honey bee pupa (Harbo and Harris 1999) have caused these dorsal dimples.

Several researchers have reported and quantified damaged mites found in honey bee colonies (Lodesani et al. 1996; Correa-Marques et al. 2000; Harbo and Harris 1999), but the types of damage were generally not described or categorized. There are few reports of live damaged mites. Lodesani et al. (1996) mentioned relatively rare damage to live mites. The proportion of live damaged mites in our study is lower than that reported by Boecking and Spivak (1999). The lack of correlation between percentage damaged mites and primary mite infestation rates demonstrates that the hive infestation rates had no significant effect on mite damage.

The colonies in our study showed on average 3\% difference in damaged mites, but the level of damaged mites may have relevance for honey bee breeding programs. Qazvin province colonies, showing higher levels of mite damage, had better characteristics in breeding programs as a consequence of grooming behaviour. This behaviour and some other resistance mechanisms must be conjugated with other economic characters, such as honey production, pollen, wax, etc., in breeding programs. We agree with Davis (2009) that it would be good to standardize terminology in future studies, and that "regular dorsal dimples" is used, instead of any indentations, hollows, depressions, or any other expression related to these types of symptoms in the dorsal idiosoma of this mite (Davis 2009). Further studies are needed in grooming behaviour to determine its effects on honey bee resistance.

Acknowledgments We would like to thank all faculty and staff members of the Department of Entomology, College of Agriculture, Isfahan University of Technology. Also we are very grateful to the Honey bee Department, Animal Sciences Research Institute, Karaj, Iran for their help in performing this study and assisting us in the project. We would like to express our special thanks to Drs. Robert L. Jeanne and Henry Hagedorn, and to two anonymous reviewers, whose constructive and valuable comments and suggestions improved this manuscript.

Open Access This article is distributed under the terms of the Creative Commons Attribution Noncommercial License which permits any noncommercial use, distribution, and reproduction in any medium, provided the original author(s) and source are credited.

\section{References}

Arechavaleta-Velasco ME, Guzman-Novoa E (2001) Relative effect of four characteristics that restrain the population growth of the mite Varroa destructor in honey bee (Apis mellifera L.) colonies. Apidologie 32:157-174

Ariana A, Ebadi R, Tahmasbi Gh (2002) Laboratory evaluation of some plant essences to control Varroa destructor (Acari: Varroidae). Exp Appl Acarol 27:319-327

Aumeier P (2001) Bioassay of grooming effectiveness towards Varroa destructor mites in Africanized and Carniolan honey bees. Apidologie 32:81-90

Bienefeld K, Zautke F, Pronin D, Mazeed A (1999) Recording the proportion of damaged Varroa jacobsoni Oud. in the debris of honey bee colonies (Apis mellifera). Apidologie 30:249-256 
Boecking O (1999) Sealing up and non-removal of diseased and Varroa jacobsoni infested drone brood cells is part of hygienic behaviour in Apis cerana. J Apic Res 38:159-168

Boecking O, Ritter W (1993) Grooming and removal behaviour of Apis mellifera intermissa in Tunisia against Varroa jacobsoni. J Apic Res 32:127-134

Boecking O, Ritter W (1994) Current status of behavioral tolerance of the honey bee Apis mellifera to the mite Varroa jacobsoni. Am Bee J 134:689-694

Boecking O, Spivak M (1999) Behavioral defenses of honey bees against Varroa jacobsoni Oud. Apidologie 30:141-158

Bozic J, Valentincic T (1995) Quantitative analysis of social grooming behaviour of the honey bee Apis mellifera carnica. Apidologie 26:141-147

Buchler R, Drescher W, Tornier I (1992) Grooming behaviour of Apis cerana, Apis mellifera, Apis dorsata and its effect on the parasitic mites Varroa jacobsoni and Tropilaelaps clareae. Exp Appl Acarol 16:313-319

Chmielewski W (1996) Body injuries of Varroa jacobsoni Oud. Females (Acarina, Varroidae) collected from hive debris of wintering bee colonies (Apis mellifera L.). Pszczelnicze-Zeszyty-Naukowe 40:141-153

Correa-Marques MH, Issa MRC, De Jong D (2000) Classification and quantification of damaged Varroa jacobsoni found in the debris of honey bee colonies as criteria for selection? Am Bee J 140:820-824

Danka RG, Villa JD (1998) Evidence of autogrooming as a mechanism of honey bee resistance to Tracheal mite infestation. J Apic Res 37:39-46

Davis AR (2009) Regular dorsal dimples on Varroa destructor-Damage symptoms or developmental origin? Apidologie 40:151-162

De Jong D, Roma DA, Goncalves LS (1982) A comparative analysis of shaking solutions for the detection of Varroa jacobsoni on adult honey bees. Apidologie 13:297-306

Eguaras E, Marcangeli K, Oppedisano N, Fernandez N (1995) Mortality and reproduction of Varroa jacobsoni in resistant colonies of honey bees (Apis mellifera) in Argentina. Bee Sci 3:174-178

Flores JM, Ruiz JA, Ruz J, Puerta M, Bustos F, Padilla M, Campano F (1995) The phenomenon of natural resistance to Varroosis. Vida Apicola 74:44-51

Fries I, Wei HZ, Shi W, Chen SJ (1996) Grooming behaviour and damaged mites (Varroa jacobsoni) in Apis cerana cerana and Apis mellifera ligustica. Apidologie 27:3-11

Guzman-Novoa E, Vandame R, Arechavaleta ME (1999) Susceptibility of European and Africanized honey bees (Apis mellifera L.) to Varroa jacobsoni Oud. in Mexico. Apidologie 30:173-182

Harbo JR, Harris JW (1999) Selecting honey bees for resistance to Varroa jacobsoni. Apidologie 30:183-196

Hoffman S (1993) The occurrence of damaged mites in cage test and under field conditions in hybrids of different Carniolan lines. Apidologie 24:493-495

Lodesani M, Vecchi MA, Tommasini S, Bilgliardi M (1996) A study on different kinds of damage to Varroa jacobsoni in Apis mellifera ligustica colonies. J Apic Res 35:49-56

Medina LM (1998) Frequency and infestation levels of the mite Varroa jacobsoni Oud. in managed honey bee (Apis mellifera L.) colonies in Yucatan, Mexico. Am Bee J 138:125-127

Moretto G (1997) Defense of Africanized bee workers against the mite Varroa jacobsoni in Southern Brazil. Am Bee J 137:746-747

Morse RA, Miksa D, Masenheimer JA (1991) Varroa resistance in U.S. honey bees. Am Bee J 131:433-434

Mossadegh MS (1992) Mites of honey bees. Ahwaz University Press, Ahwaz, Iran

Peng YS, Fang Y, Xu S, Ge L (1987a) The resistance mechanism of the Asian honey bee, Apis cerana to an ectoparasitic mite Varroa jacobsoni Oud. J Invertebr Pathol 49:54-60

Peng YS, Fang Y, Xu S, Ge L, Nasr ME (1987b) Response of foster Asian honey bee (Apis cerana) colonies to the brood of European honey bee (Apis mellifera L.) infested with parasitic mite, Varroa jacobsoni Oud. J Invertebr Pathol 49:259-264

Rosenkranz P, Fries I, Boecking O, Sturmer M (1997) Damaged Varroa mites in the debris of honey bee (Apis mellifera L.) colonies with and without hatching brood. Apidologie 28:427-437

Ruttner F, Hanel H (1992) Active defense against Varroa mites in Carniolan strains of honey bee. Apidologie 23:173-187

Szabo TI (1999) Selective breeding of honey bee colonies for resistance to Varroa jacobsoni and the effects of management techniques on Varroa infestation levels. Am Bee J 139:537-540

Szabo TI, Walker CRT, Mueller AEM (1996) Grooming behaviour as a Varroa resistance characteristic in honey bee colonies. Am Bee J 136:515-517

Thakur RK, Bienefeld K, Keller R (1997) Varroa defense behaviour in Apis mellifera carnica. Am Bee J 137:143-148

Vandame R, Colin ME, Otero-Colina G (1999) Varroatoleranz der Afrikanisierten bienen in Mexiko: Die unfruchtbarkeit der milbe ist kein hauptfaktor der toleranz. Apiacta 34:12-20 